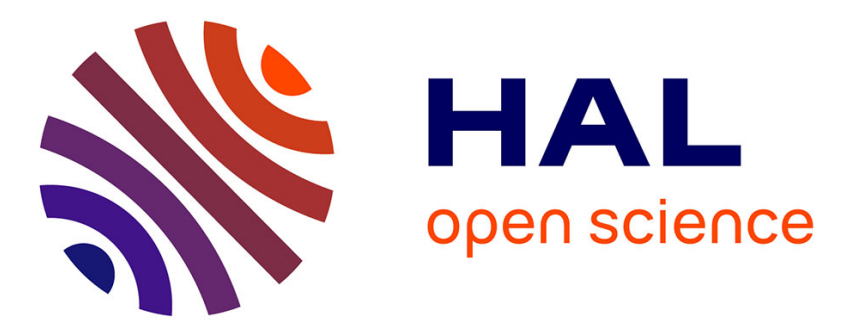

\title{
Uncertainty on evapotranspiration formulation and its hydrological implication under climate change over France
}

Thibault Lemaitre-Basset, Ludovic Oudin, Guillaume Thirel, Lila Collet

\section{To cite this version:}

Thibault Lemaitre-Basset, Ludovic Oudin, Guillaume Thirel, Lila Collet. Uncertainty on evapotranspiration formulation and its hydrological implication under climate change over France. EGU 2021, May 2021, Paris, France. 10.5194/egusphere-egu21-9946 . hal-03266281

\section{HAL Id: hal-03266281 \\ https://hal.inrae.fr/hal-03266281}

Submitted on 21 Jun 2021

HAL is a multi-disciplinary open access archive for the deposit and dissemination of scientific research documents, whether they are published or not. The documents may come from teaching and research institutions in France or abroad, or from public or private research centers.
L'archive ouverte pluridisciplinaire HAL, est destinée au dépôt et à la diffusion de documents scientifiques de niveau recherche, publiés ou non, émanant des établissements d'enseignement et de recherche français ou étrangers, des laboratoires publics ou privés. 
EGU21-9946, updated on 21 Jun 2021

https://doi.org/10.5194/egusphere-egu21-9946

EGU General Assembly 2021

(c) Author(s) 2021. This work is distributed under

the Creative Commons Attribution 4.0 License.

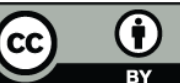

\title{
Uncertainty on evapotranspiration formulation and its hydrological implication under climate change over France
}

\author{
Thibault Lemaitre-Basset ${ }^{1,2}$, Ludovic Oudin ${ }^{1}$, Guillaume Thirel ${ }^{2}$, and Lila Collet ${ }^{2}$ \\ ${ }^{1}$ Sorbonne Université, CNRS, EPHE, UMR METIS, Case 105, 4 place Jussieu, F-75005 Paris, France \\ ${ }^{2}$ Université Paris-Saclay, INRAE, HYCAR research unit, Hydrology Research Group, Antony, France
}

Climate change might cause regional modifications of precipitation regimes and increase of air temperature and evaporative demand. As a consequence, the potential increase in evapotranspiration has been determined as a key risk, which could lead to a decrease in runoff and water resources. In many hydrological models, evapotranspiration is determined by a preliminary computation of the evaporative demand, potential evapotranspiration (PET). Estimating PET for future climate is still subject to extensive research, due to the multiplicity of PET formulations and the uncertainties associated with the climatic variables used within these formulations. Physically-based PET formulations use several climatic variables whose simulations come with large uncertainties, while more simple empirical PET formulations rely on limited climatic variables. However, their empiric development questions their robustness for transient climatic conditions.

In this work, we examined the evolution of PET under future climate conditions. We also investigated to what extent seven different classical PET formulations could modify the partitioning of uncertainty associated with climate projections.

The importance of PET formulation on the total uncertainty of the potential evapotranspiration changes was evaluated within a multiscenario multimodel ensemble (Euro-CORDEX climate projections from CMIP5 experiment) over the whole France. This approach was used to account for the uncertainty on the unknown future greenhouse gas emissions trajectories, and differences coming from climate models (GCMs and RCMs). An analysis of the variance (ANOVA), allowed us to determine the contribution of each modelling step to the total uncertainty of PET estimates over entire France. The ANOVA was applied on an ensemble completed by a Bayesian process, to have a balance set of projections to analyze.

The results showed that the relative importance of PET formulations was found to be minor compared with other uncertainty sources (GCMs and RCMs) in the future. We also found that divergences of PET among the different formulations were highly dependent on the temperature anomaly. Based on our experimental design, we concluded that the choice of PET formulation might not constitute a major element of uncertainty reduction for hydrological projections. 